Michael Cuntz

\title{
Monturen/montures: On Riding, Dressing, and Wearing. Nomadic Cultural Techniques and (the Marginalization) of Asian Clothing in Europe
}

In this text, I would like to link together three things: 1) elements of the history of the French word monture and its German loanword Monturen; 2) elements of the history of denying Asian influences through a long tradition of European exceptionalism, which I examine using the "example" of textiles and clothing; and 3) the resulting suppression of the Asian, nomadic, and interspecific origins of supposedly typical European garments that emerged from the domestication of horses on the Eurasian steppe. In doing so, I will attempt to bring together several traces and fragments of Eurasian processes for exchanging cultural techniques, living beings, and artifacts. In view of the geographical and temporal expansiveness of this macrohistory, my argument necessarily proceeds in leaps.

\section{Words and Things}

The question of the relation between words and things is no minor matter for an approach based in cultural techniques. It is thus significant that André-Georges Haudricourt, who will play a significant part in the second half of this essay, had a dual career - on the one hand, as an explorer of ensembles of technical objects, techniques of the body, and domestications, as well as their migration; and as a linguist, on the other. Yet this one side/other side is a separation that results from his appraisal by isolated professional communities, and that severs the indissoluble connection existing between words and things. ${ }^{1}$ If one discredits, from the vantage point of an "enlightened" awareness of the complete arbitrariness of signs, the interest in words as objects of knowledge as cratylistic naïvety, that is, a naïvety that assumes a factual correspondence between things and words, then this in turn is based on a naive thinking of factuality, which believes that the

1 See Michael Cuntz, "Kommentar zu André-Georges Haudricourts 'Technologie als Humanwissenschaft,"” Zeitschrift für Medien- und Kulturforschung 1, 1 (2010): 89-99.

Translated by Michael Thomas Taylor 
mode of existence of the things in the world, or facts, are given independently of human manipulations.

It is precisely where there is talk of domestication, as will be the case in what follows, that the divide between nature and culture is always already overgrown by a web of connections between the two of them, which renders untenable the containment of existences fabricated in such a way within a purely human sphere of social constructions. If one assumes that there is no world "behind" our fabrications, our faitiches, ${ }^{2}$ but rather a pluriverse ${ }^{3}$ of worlds consisting of such fabrications, of worlds that overlap and exist in and through (discursive) exchange, then the critical uncoupling of words and things appears as the mutilation of a web in which actors, signs, materials, and milieus support and influence each other. But even staunch relativists would have to acknowledge that cultural techniques and, at least in part, their migratory movements have become sedimented in words. And even more so: that the naming and designating of actors, things, and operations is also a central cultural technique.

\section{Montures/Monturen}

I therefore begin this text by exploring a centuries-old process of migrations and shifts, between French and German, in the word pair "monture/Montur." The word "Montur" is no longer very common in German. It is most frequently used in the phrase "in voller Montur" ("in full kit"), where it refers to clothing and accessories, that is, to what one wears on one's body. It is used to denote a person who is optimally equipped, possibly even over-equipped. When used ironically in this sense, it means something like "Aufzug" (an "oufit," "getup," or "costume”). In some areas of southwestern Germany, such as on the Moselle River or in Saarland, Montur therefore also refers to "all of a woman's clothing” in the sense of a complete outfit with textile objects that are often seen as mere attire (Rheinisches Wörterbuch). ${ }^{4}$

On the other hand, according to Duden, it can also mean that one wears clothes for "a certain purpose," and hence perhaps for something other than an

\footnotetext{
2 See Bruno Latour, Sur le culte moderne des dieux faitiches, suivi de Iconoclash (Paris: La Découverte, 2009).

3 William James, A Pluralistic Universe: Hibbert Lectures at Manchester College on the Present Situation in Philosophy (New York: Longmans, Green \& Co., 1909).

4 For the other German-language dictionaries listed below, unless otherwise stated, as well as for Meyers Großes Konversationslexikon, quotes are from http://www.woerterbuchnetz.de (visited on July 21, 2019); translations by Michael Thomas Taylor.
} 
everyday occasion. ${ }^{5}$ This purpose is often work: Monturen are the liveries of servants or certain work clothes, for example, clothes worn by a mechanic.

But the reference to clothing is already a narrowing, because the word "Montur" - or as it was originally used in German, "Montierung" - indicates not only clothing but, analogously to the English word "outfit," also all the equipment or objects that accompanied an outfit, and specifically, the outfitting of soldiers. In addition, "Montur" designates, in both German and French, a setting in which something is fastened, such as precious stones. ${ }^{6}$ The connection with "montieren" in the sense of a "Montage" is obvious: the soldier is thus a classic network actor capable of acting only in collaboration with the multitude of his objects. We thus find a soldier literally equipped, or montiert, in Meyers Konversationslexikon (published from 1905 to 1909):

\footnotetext{
Montierung (in Österreich Montur, franz.), die Ausstattung des Soldaten, die ehedem jedem einzelnen oblag, bis mit Einführung der stehenden Heere der Staat es übernahm, die Truppen zu montieren, d. h. auszurüsten.

Montierung” (in Austria, the French word, "Montur," is used), the outfitting of a soldier, which was formerly the responsibility of each individual, until the state took over the task, upon the introduction of the standing armies, of outfitting, i.e., equipping, the troops.
}

The verb "muntieren" can already be found in Middle High German (Lexer). ${ }^{7}$ And the Schweizer Idiotikon contains the following example of usage from the year 1673: "Pferd, das mundiert ist zum Streit" ("a horse that has been equipped [mundiert] for battle"). ${ }^{8}$ Even if here it is, curiously, the horse itself that is equipped for battle instead of being the rider's equipment: this brings us closer to the starting point of this word history, because the first meaning of the French word "monture," for which we find examples going back to 1360 (Petit Robert), and from which all further word migrations with their semantic shifts are derived, is nothing other than mount, or riding animal, and, at least in the European context, the riding animal par excellence, the horse. To "montieren" something, or to put it together, i.e., assembler, is therefore derived from mounting something, and specifically, the mounting of an animal: The "monture" is that which is mounted; horse and rider, carrier and carried, together form an assemblage, and this basic constellation is repeated in the setting or the frame that carries something in or even on itself.

5 https://www.duden.de (visited on July 21, 2019).

6 https://www.duden.de/ (visited on July 21, 2019); Le Nouveau Petit Robert: Dictionnaire alphabétique et anthologique de la langue française (Paris: Le Robert, 1996).

7 Matthias Lexer, Mittelhochdeutsches Handwörterbuch, 3 vols. (Leipzig: Herzel, 1872-1878).

8 Schweizerisches Idiotikon, https://www.idiotikon.ch/ (visited on July 21, 2019). 
In the migration of the word from French into German and between different contexts of use and social situations, a whole series of remarkable shifts occur. Not only the transition from the military sphere to the sphere of servants and work, up to the change in gender to women's clothing with its accompanying connotations of ridiculousness and frivolity; also the simultaneous reduction, to clothing and useless accessories, of what previously referred to useful and necessary equipment, which additionally, or primarily, included a domesticated living being. For the most radical revaluation already took place in the shift from French to German: from the elevation of the knight, who looks down from his mount upon those who are of low birth, to the humiliation of the soldier-servant who is likewise marked and equipped by his master. ${ }^{9}$ Saying that these subalterns occupy the symbolic place of the horse would arguably mean underestimating the economic value of the horse.

Hence, in French, the meaning of the word already shifts from a monture for a riding animal to monture in the technical sense, or montage, which nevertheless does not appear in French until nearly four hundred years later, in the middle of the eighteenth century ${ }^{10}$ - of course because monter contains the sense of "to erect, to set upright," and I would suggest that the conceptual proximity (which also exists, by the way, in the verb "dresser") is no coincidence. This is not only because the elevation of a person's point of view - or, to be more precise, the point where a person sits - to that of a mounted rider, and especially of a rider on horseback, has been the most important uprighting since humans began to walk on two legs, but also because horse and rider, as well as the articles of clothing and equipment (reins, bridles, tack, and saddles) and the gestures and techniques of the body required to ride an animal, likely form one of the most complex cultural-technical montages and assemblages of all. This assemblage is an interspecific history of technology, an emergence of interspecific network actors, that required a long period of preparation and, in its assembly, an alignment between

\footnotetext{
9 Adelung, "Montur," quoted from http://www.woerterbuchnetz.de; in Adelung, it is clear that the "common soldier" is nothing but a variant of the servant: both are equipped and outfitted by their master to be marked as property. On the meaning of liveries as a badge of servitude, or rather of servility, see also Thorstein Veblen, The Theory of the Leisure Class (Oxford: Oxford University Press, 2007 [1899]).

10 The Petit Robert gives 1740 as the year for the use of monture in the sense of a frame or setting. Whereas Nicot's Thrésor de la langue française from 1606 still presents monture exclusively as mount, the word "monture" appears in the fourth edition of the Dictionnaire de l'Académie française from 1762 in the sense of rack (of a cannon) or setting/frame, and hence expressly as assemblage: “L'assemblage des deux pièces d'une tabatière ou d'un étui, jointes l'une avec l'autre." The ARTFL project, Dictionnaires d'autrefois, http://portail.atilf.fr/dictionnaires/onelook.htm (visited on July 21, 2019).
} 
humans and animals. Moreover, if one follows Jean-Pierre Digard (an expert on domestication), ${ }^{11}$ and thus an approach established by André Leroi-Gourhan that is marked by attention to cultural techniques, this is also a history that was possible only via several detours: horse and rider constitute a monture, a montage, a small collective unit in a cultural-technical ensemble that was prepared over thousands of years. ${ }^{12}$

This interspecific montur/montage therefore forms the core for a reflection of the connection between things, persons, and other animate actors, as well as actions and habits, which is my aim in what follows. This consideration concerns the history of clothing that is completely familiar to us and supposedly typical for the West, and that takes us far away from today's Europe in space and time. It must also make headway in the face of a double resistance of disdain and contempt: European disdain for Asia that reaches back thousands of years, as well as the equally ancient contempt that settled peoples (who consider only themselves to be civilized) have toward nomads. At least the latter has a great deal to do with the question of the relationship between humans and animals, or with an anthropocentric world view. It is only by distancing oneself from such a condescending perspective - and this is something I will be tracing in what follows in relation to Asian textiles and garments - that it becomes clear how nomadism, domestication, and riding on the steppes of Asia are related to the development of techniques of the body for wearing clothing, as well as to the development of certain articles of clothing. This is not only a cultural issue, but also one of the connections between habits and riding habits.

\section{Covers, Accessories, Spices: The Supplementary Topology of Exotica}

It is therefore also necessary to speak about the attitude of European philosophers and scholars toward Asian textiles, because the puritanical and xenophobic affect aroused by exotica from Asia and the condemnation of their consumption as senseless waste or even a corruption of moral values can be traced back, in

11 Jean-Pierre Digard, Une histoire du cheval: Art, techniques et société (Arles: Actes Sud, 2007). 12 This is especially true if one assumes, with Digard, that horses were not domesticated to be ridden, but rather that riding horses arose much later; see Digard, Une histoire du cheval, 39. 
Europe, at least to the branding of silk as the epitome of luxuria ${ }^{13}$ in Rome. ${ }^{14}$ It was apparently inconceivable that Europeans - and even more so, European men might wear Asian textiles. Upon encountering the enthusiasm of rich Roman women for silk, Pliny the Elder was, not without good reason, concerned about Rome's stock of precious metals. ${ }^{15}$ Seneca, by contrast, took moral offense at just how transparent and flowing this fabric was. ${ }^{16}$ Tacitus reports that Roman men were forbidden by decree to dress in this "feminine" fabric. ${ }^{17}$

Pliny was consistent enough to also condemn amber or frankincense. Yet as Fitzpatrick clearly shows, Seneca's stoic invectives against Asian luxury goods served the same function as do the sermons held by today's defenders of national values and national economies. ${ }^{18}$ They function as a hypocritical distraction from the more profane things that made up thelion's share of this trade, as wellas from the facts of just who, exactly, was importing it at such a handsome profit: namely, the members of the Roman Senate (in its plutocratic constitution, which proved exemplary for later occidental empires), who accumulated their enormous fortunes primarily through trade with the East. Seneca had no trouble distinguishing between respectable wealth and offensive luxuria. ${ }^{19}$ Which obviously meant not only: behave with dignity worthy of a Roman, but also wear real Roman clothing. For the money earned via long-distance trade, on the other hand, it was and remains true: non olet.

The textiles and garments that migrated from Asia to Europe are more than just exotic accessories, and the issue was not only the conspicuous consumption

13 Even more so than luxus, luxuria bears the connotations of moral and sexual depravation, a differentiation that persists in the different semantic values of French luxe (luxury) and luxure (lust). Luxuria is directly linked to voluptas.

14 To call Romans Europeans is a shortcut rooted in the fact that today's Europeans consider themselves the heirs of Greek and Roman culture. Of course, this equation between Greeks and Romans, on the one hand, and modern Europeans, on the other, must be deconstructed. Still, even if Romans like Pliny and Seneca were not Europeans: what they share with (many of) today's Europeans is their anti-Asian affect.

15 It can in fact be shown that Roman silver circulated in Asia on a large scale; see M. P. Fitzpatrick, “Provincializing Rome: The Indian Ocean Trade Network and Roman Imperialism,” Journal of World History 22, 1 (2011): 27-54, here 50.

16 Peter Frankopan, The Silk Roads: A New History of the World (London and New York: Bloomsbury, 2015), $17 \mathrm{f}$.

17 In a fashion that is equally absurd and consistent, this attitude is also transferred to riding: even the Greeks (Xenophon, for example) praise "bareback riding" and mock the riders of their Asian opponents as effeminate because they use saddles and blankets; see Digard, Une histoire du cheval, 68.

18 Valerie Hansen, The Silk Road: A New History (Oxford: Oxford University Press, 2015), 20. 19 See Fitzpatrick, "Provincializing Rome," 32. 
of the ruling elite, even if this consumption was a strong driving force for both the peaceful and not so peaceful movement of coveted goods. ${ }^{20}$ From the outset, it was important for subordinates to share in the profit from the flow of exotic goods, with the consequence that these goods became more common not only in the upper social stratum. ${ }^{21}$

Given the deep penetration of Asian goods into the West, the fact that it was exotic fabrics and garments, as well as spices, against which the Western imaginary constituted itself is perhaps anything but a coincidence in this context: ${ }^{22}$ these goods stand metonymically for a view of "foreign" objects that, like covers or shells and spices, merely envelop and refine - or even supplement ${ }^{23}$ - what is authentic, the genuine core, body, or food, and that can also be omitted if necessary, as for example in Renaissance France, where, long before "freedom fries," we find invectives against strongly seasoned food as an "un-French" corruption of national palates. But for millennia, thanks to economic-cultural exchange processes within long networks that would not have existed without montures like horses and camels, it is impossible to uncover, anywhere in Eurasia, the core of an "authentic" culture from beneath purely external additions. Instead, everywhere we encounter transcultural Monturen and assemblages.

\section{Riding Pants and Centaurs: Palmyra - Sampul}

What would Seneca and Pliny, both so offended by the transparent, unmanly fabric of silk, have said about the clothing worn by the inhabitants of Palmyra? In that city on the eastern edge of the Empire, which Rome had subdued a century before these philosophers lived, because the city was one of the gateways to trade with Asia, these two men would have seen many people dressed in a completely un-Roman fashion. Instead of wrapping lengths of wool or linen around their bodies and attaching them with clasps, as was customary in Greece and the

20 Paul Treherne, “The Warrior's Beauty: The Masculine Body and Self-Identity in Bronze-Age Europe," Journal of Historical Geography 3, 1 (1995): 105-144.

21 Barry Cunliffe, By Steppe, Desert, and Ocean: The Birth of Eurasia (Oxford: Oxford University Press 2015), 94f.

22 See Stefan Halikowski Smith, “The Mystification of Spices in the Western Tradition,” European Review of History/Revue européenne d'histoire 8, 2 (2001): 119-136.

23 On the logic of the supplement, see Jacques Derrida, De la grammatologie (Paris: Minuit, 1967), 203-234. 
Roman Empire, and with sandals bound to their feet, these people dressed in a "Persian" manner: ${ }^{24}$ with boots and pants. ${ }^{25}$

This image of a "topsy-turvy world" in which the Persians appear to be the progenitors of our present-day clothing style rather than the Greeks (who would presumably consider us to be Asian barbarians because of our clothing), is more than a snapshot of history, for the form of many garments worn by Europeans and their descendants that we consider to be specifically European comes from Asia as well as the way they function, meaning how clothing is put on and taken off, how it clings to the body and envelops it. Clothes, namely, cannot be separated from certain gestures, such as wrapping or covering up, or from cultural techniques. If one traces these gestures and techniques, it becomes clear that a person quite literally "carries" or "bears" clothing.

Furthermore, it appears that this "Persian" clothing is closely linked to the history of the horse's domestication - not primarily because the horse's skin (in the form of leather) or its coat (in the form of felt made of horsehair) would have provided the materials for this clothing, but because of the techniques of using horses as a means of transport, which has had consequences for the human body. I'll return to all of this later.

Still, it's not enough to travel to the Middle Eastern metropolis of Palmyra, because the Eurasian processes of exchange do not consist solely of encounters among diverse things and peoples at the margins of their respective territories and spheres of influence. On the contrary, early traces of fusioning can be found in far more remote places, which in turn prove, from a less Eurocentric perspective, to be central crossroads of the trade routes: Sampul, which today lies in Xinjiang province in western China but belonged, in the third century AD, to the kingdom of Khotan, which had been founded by steppe nomads. Graves from this time were found to contain a leg from a pair of woolen men's pants. (Fig. 1) This leg was in turn cut from a tapestry originating from the Parthian Empire. It shows the depiction of a centaur, a being from the Greek mythical world modeled, according to today's view, after nomadic equestrian peoples of the Asian steppe armed with bows. The tapestry probably originates from the Parthian Empire; the floral motifs on the

24 Interestingly, the Roman Empire also invented the corresponding footwear for horses known as hipposandals; see, e.g., A. D. Fraser, "Recent Light on the Roman Horseshoe," The Classical Journal 29, 9 (1934): 689-691.

25 Paul Veyne, Palmyre: L'irremplaçable trésor (Paris: Albin Michel, 2015), 12. This is also reflected in the depictions on the necropolis of Palmyra, which testify to the mixture of Greek and Parthian lifestyles: "The couches, drinking vessels, and hairstyles might be Hellenistic, but the long robes that clothe these figures are similar to those of the Parthians.” See Xinru Liu, The Silk Road in World History (Oxford: Oxford University Press, 2010), 29. 
collar of the warrior and the cloak of the centaur are of Central Asian origin, but the centaur motif spread deep into Asia, as far as Northwest China, and primarily where nomadic equestrian peoples lived. ${ }^{26}$ If one follows the widely accepted thesis that the origin of the centaur myth lies in the perception of such Asian nomadic peoples on horseback by the early Greeks (who were themselves not familiar with horses and certainly did not ride them), then these riders were not only confronted with representations of this mythical image but apparently also willingly integrated them into their culture. Was this a form of self-reflexivity in relation to the fusion of rider and horse into a single entity, a mounted actor?

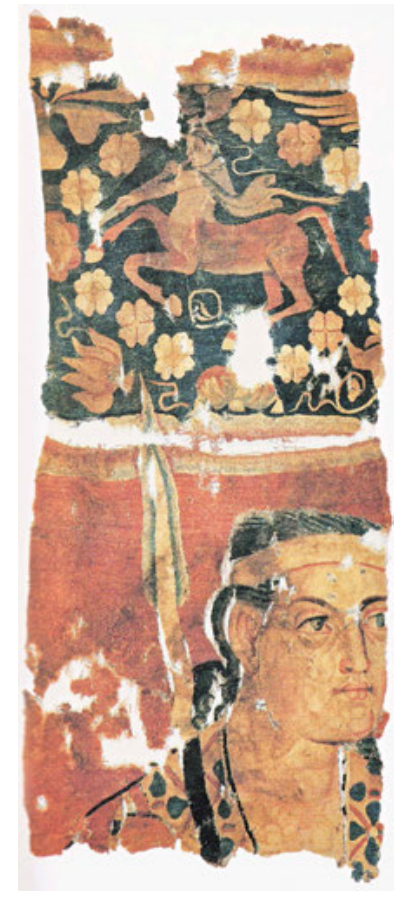

Fig. 1: Woolen Trouser Leg from Khotan.

The history of the horse's domestication leads us not only to Asia, but also away from the settled "high" cultures to the nomads of the steppes: first to the Scythians, then to the Turkic peoples and the Mongols, who were regarded for quite some time as being culturally inferior (otherwise the term "high culture" would not exist) and came to inspire respect (and fear) only when they conquered the urban realms of settled peoples, which itself gives evidence of the Mongols'

26 See Liu, $198 \mathrm{ff}$. 
superior military techniques and tactics. ${ }^{27}$ In the representation and assessment of the contact between the nomads and the settled peoples they subjugated, cultural transfer is often conceived in only one direction, as a one-way street: It is in terms of the "wild" nomads who, after initially wreaking havoc, adopt the superior civilization. This attitude can be found even in some authors who are determined to correct the Eurocentric view of history by giving due consideration to Asia. In Jack Goody's The Theft of History, for example, the Mongols only appear as interrupters of trade between Europe and the Middle East; ${ }^{28}$ beyond that, Goody mentions the Mongols only in noting that they adopted gunpowder from the Chinese. ${ }^{29}$ For Goody, culture is always synonymous with urban culture. Things are similar with S. Frederick Starr, who argues that the Mongols were only able to maintain their rule by parasitically exploiting the abilities of others, whether in administration or science. ${ }^{30}$ Unfortunately, Starr's rehabilitation of the urban cultures of Central Asia comes at the expense of these "culture-less" nomads - a perspective expressed in his work not least of all in a blatant Arabophobia. Barry Cunliffe makes a similar remark, ${ }^{31}$ but the central claim of his book is that the Eurasian space was, for millennia, able to function only through permanent exchange between settled and nomadic cultures.

\section{What's with the Hats? Hennins and Panni Tartarici}

In his history of the Silk Road, Peter Frankopan also pushes back against this disparaging view in emphasizing not only the outstanding postal infrastructure of the Mongol Empire (which was of course based on horsemen) but also, as Marco Polo and Rustichello da Pisa had pointed out centuries earlier, ${ }^{32}$ on the administrative and political skills of these rulers, which were based on tolerance

27 Jacques Paviot describes this shift of perception from fear to interest; see "England and the Mongols (c. 1260-1330)," Journal of Royal Asiatic Society, Series 3, 10, 3 (2000): 305-318.

28 Jack Goody, The Theft of History (Cambdrige, UK: Cambridge University Press, 2010 [2006]), 111 and 113; here, Goody writes of "Mongol invasions and other disturbances." The term "nomad(s)" is not found in the index to Goody's book.

29 Good, Theft of History, 103.

30 S. Frederick Starr, Lost Enlightenment: Central Asia's Golden Age from the Arab Conquest to Tamerlane (Princeton: Princeton University Press, 2013), 450f.

31 See Cunliffe, By Steppe, Desert, and Ocean, 424.

32 Marco Polo and Rustichello da Pisa, Devisement ou Description du Monde (1298). 
(including religious tolerance) and open-mindedness. ${ }^{33}$ The question is thus justified of whether these nomads were also more intellectually agile than many of their settled neighbors.

Frankopan furthermore points out how the Mongol empire, founded by nomads, influenced both high culture and everyday life, after its expansion in the thirteenth century, not only in China but also in India and Europe. ${ }^{34}$ While he concludes that the Mongols had an influence on China's culinary habits, when he turns to Europe he notes the influence of Mongol clothing on fashion. For example, he argues that the hennin, which European women wore in the fourteenth and fifteenth centuries, is directly inspired by Mongol head-coverings. (Fig. 2) In addition, the emblem of the Order of the Garter, known above all for its

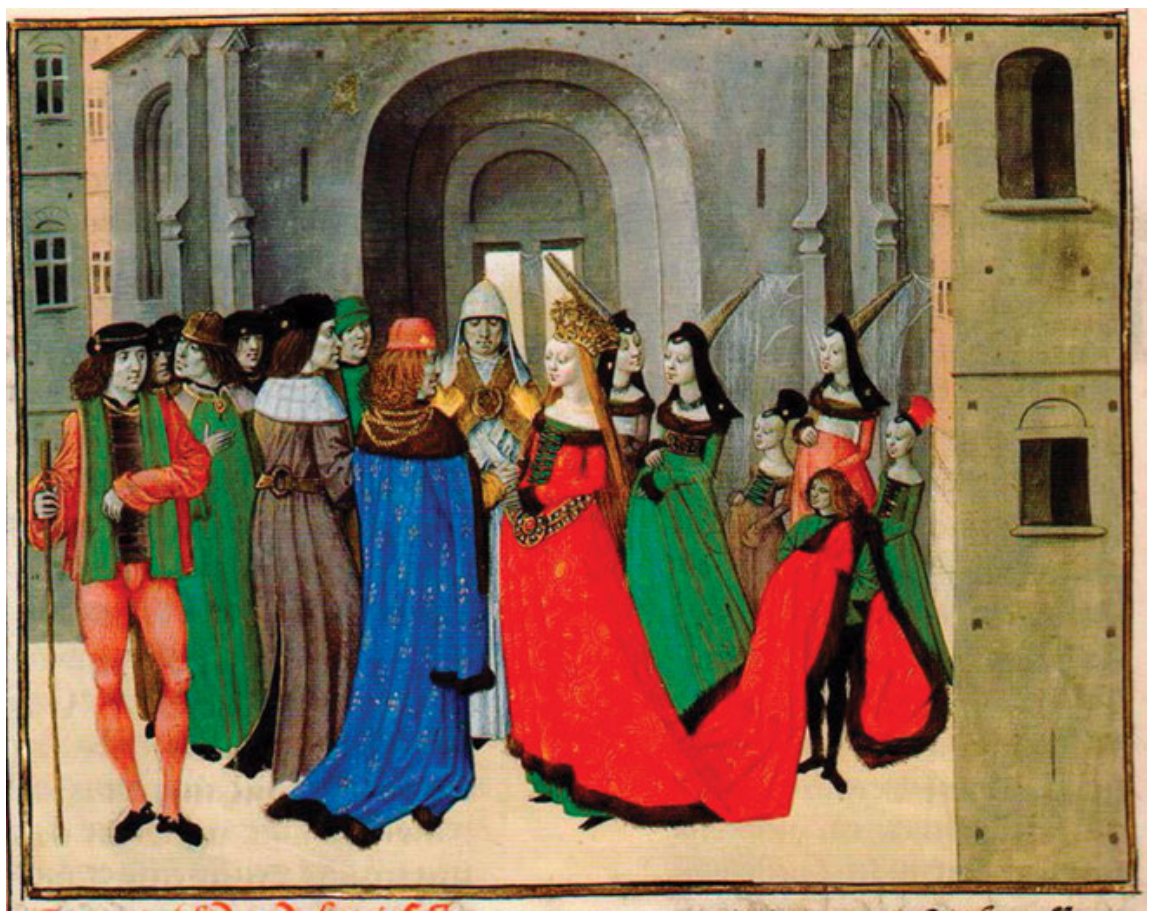

Fig. 2: Women wearing Hennins (right), a man wearing a vest (left), which did not exist in Europe before the very late Middle Ages (Jean Froissart, Chroniques, $3 \mathrm{~d}$ book, page from an illuminated manuscript [detail], J. Paul Getty Museum).

33 Peter Frankopan, The Silk Roads: A New History of the World (London: Bloomsbury, 2015), $177 \mathrm{ff}$.

34 Frankopan, The Silk Roads, $180 f$. 
motto "honi soit qui mal y pense" (the old French literally means: "shame on him who thinks badly of it"), was made of "Tatar cloth." 35

Indeed, from the thirteenth century onwards, what was known as panni tartarici - silk interwoven with gold or silver threads, a kind of brocade fabric made in Central Asia - enjoyed great popularity throughout Europe as prestigious luxury textiles. ${ }^{36}$ These fabrics were extremely popular with the Mongols (called Tartars by the Europeans); and the Mongols were doubly responsible for their spread in Europe: on the one hand, because the Europeans wanted to imitate the Mongol's clothing style; and on the other, because trade between Europe and Asia flourished due to the safety of the routes in the Mongol Empire (and the elimination of the Arab middlemen, which went hand in hand with an increasing tendency to generally view the Mongols as allies against the "Saracens"). The panni tartarici were thus available in significant quantities.

The panni tartarici and hennins - or conical headdresses, as the latter were also called - even belong together, because these headdresses were often decorated with "goldcloth” or "drap d'or," as Gustaaf Schlegel (a renowned Dutch sinologist who, among other things, researched the emergence of gunpowder and engaged with geographical reports in Chinese historiography) wrote at the end of the nineteenth century. ${ }^{37}$ Schlegel also explains that the hennins can be traced back to the sixth century AD, where they are found among the Hepthalites (belonging to the Huns) and were common among the Kyrgyz and Kazakhs up until his own day (and such hats are still worn today in Asia). This headdress of these Asian nomads thus has a long tradition.

The image of European women in the fifteenth century was also shaped by the hennin. That said, one would probably hesitate to ascribe to panni tartarici and hennins any fundamental significance for how Europeans dress. Yet the way in which their significance is marginalized is striking. In the one paragraph that Frankopan dedicates to both items, he speaks of "new fashions," describing the Mongol style as "modish" and the hennin as "fashion accessory." Hence here, again, this argumentation operates according to the logic of spices in relation to food, namely as a mere accessory (would Frankopan also call the bowler an

35 Two decades after the foundation of the order, Andrea de Bonaiuto still makes this connection when he depicts, in his 1368 frescoes for Santa Maria Novella in Florence, a Mongol in conversation with an English knight of the Order of the Garter; see Paviot, "England and the Mongols," 318.

36 See, for instance, Geertje Gerhold, in Berichte und Forschung aus dem Domstift Brandenburg, vol. 2 (2009): 187-204, here 189f.

37 Gustaaf Schlegel, “Hennins or Conical Lady's Hats in Asia, China and Europe,” T'oung Pao 3, 4 (1892): 422-429, here 424. 
accessory?) that is connected to the ephemerality of fashion and thus marked as a passing fancy.

And even as late as the year 2000, Jacques Paviot's portrayal of Asian clothing still conveys such an impression of marginality for Europeans. His text on the Mongol craze that swept England in the thirteenth and fourteenth centuries offers only a concluding note about clothing; at a jousting tournament held on September 21, 1331, King Edward III and his entourage dressed (up) like Mongols with capes made of camel hair, among other things. It is precisely the highlighted singularity of this event that makes it appear as a kind of carnival or primal scene of Oriental exoticism in Europe. And this is no coincidence, because the fact that Mongol clothing, in Paviot's argument, slips into secondary importance is itself a symptom of the "decay" of England's relations with the Mongol empire. It symbolizes the fading away of a temporary fascination with the Mongols that was a mere episode leaving no lasting political or cultural traces. Instead of cultural imprinting, we are apparently dealing here with a momentary infection, like a cold that must be waited out.

Although it is more discreet and implicit, an attitude prevails here that is even more blunt in Schlegel's assessment of the hennin a century earlier. Even if Schlegel's aim is to prove that trade relations with Asia were already quite close in the Middle Ages, he does not get much from hennin. Schlegel, whose view of top hats was apparently so overly habitualized that he could not reflect on their shape, constantly mocks the monstrous height of this headpiece; he quotes the phrase "curious head-dress" from Viollet-Le-Duc, and even goes beyond him with phrases like "extravagant headdress," "ridiculous fashion," "foolish fashion," and "strange and absurd fashion." ${ }^{38}$ Schlegel furthermore mentions it was via Mongol rule that this headdress fashion also reached the Chinese court, where it dominated from the eleventh to the fourteenth centuries, despite decrees against it. The hennin arrived in Europe via rich Flemish merchants. Schlegel notes that European contemporaries had already reacted to the garment with mockery and abuse; among other things, he mentions a priest whose sermons railed against the cone-shaped headdress. Schlegel closes with the words:

We have already proved in a former article, that the ridiculous fashion of Crinoline, with the reappearance of which we are now again threatened, was likewise introduced from Asia, as also the still more ridiculous fashion of the Mouches or patches-of-beauty, which the European ladies pasted upon their faces in the 18th century. ${ }^{39}$

38 Schlegel, Hennins, 424, 425, 426, 428.

39 Schlegel, Hennins, 429. 
Of course, it is no coincidence that the notorious moralist Schlegel only targets the transgressions of women's fashion brought in from Asia. Whether the opponent of the hennin is Seneca, the fifteenth-century priest who attempted in vain to exorcise the devilish horned hennin, or the erudite scholar Schlegel: the issue is always controlling female madness that falls victim to Asian decadence, and thereby, above all, defending male reason and masculinity threatened by Asian effeminacy, and thus ultimately defending the decency of Europe.

Perhaps the writer Julien Gracq had the better intuition in comparing the hennin to the horn of a unicorn, the animal that stood for purity and could be tamed by virgins. ${ }^{40}$ Perhaps the hennin was appropriated precisely as a symbol of purity in the Christian context, an insight that escaped Schlegel's phalloeurocentrism, which felt threatened by high women's headdresses.

However, as the pants and boots in Palmyra in fact show, the influence of Asian nomadic peoples on European clothing can be limited to neither women nor fashion.

\section{The Nomadic Genealogy of Pants and Boots: Monturen in Equestrian Cultures}

This directly or indirectly has to do with the domestication of the horse. It is not the mere fact of this domestication that is crucial here, but its development and the changing practices and techniques in which these animals were involved. Although it is difficult to accurately reconstruct the origins of its domestication, it can only have taken place in the milieu of the steppe, where horses still survived after intensive hunting by prehistoric humans. Even if it is possible that this process was multicentric, the thesis accepted today is that it took place in the fifth millennium BC in the region of the Pontic-Caspian steppe, ${ }^{41}$ with localizations varying between present-day Ukraine ${ }^{42}$ and present-day Kazakhstan. ${ }^{43}$

40 "hennins qui tanguent raidement à chaque mouvement du cou comme la corne de la licorne" (Gracq), quoted from http://encyclopedie_universelle.fracademic.com/47471/hennin (visited on July 22, 2019).

41 David W. Anthony, The Horse, the Wheel, and Language: How Bronze-Age Riders from the Eurasian Steppes Shaped the Modern World (Princeton: Princeton University Press, 2007), 134ff.

42 Jean-Pierre Digard, Une histoire du cheval, 42.

43 Cunliffe, By Steppe, Desert, and Ocean, 77f. 
If one follows Jean-Pierre Digard, the development occurred in stages similar to the domestication of the reindeer: at first the horse served only as food, which has remained the case on the steppes of Asia. In a next step, a millennium later, the horse was used as a pack animal and then as a draft horse, and only in a final step did the technique of riding develop (the riding saddle is congruently derived from the Mongol pack saddle). ${ }^{44}$ Developments in military technology correspond to this process: the invention and use of chariots long preceded the development of cavalry. ${ }^{45}$ The use of a complex vehicle, which also required the invention of the wheel and the axle, was thus a necessary detour, as it were, on the way to a supposedly closer, immediate connection between people, animals, and weapons technology. If one follows Digard, this would be evidence of the effort and process of cultural co-evolution represented in the assembling together of horse and rider. ${ }^{46}$

The natural milieu also played its part in this development: Riding horses originated in mountain regions where it was not possible to use chariots, unlike on the plains of Mesopotamia or in northern India, for example. ${ }^{47}$

Digard makes clear how close, even symbiotic, this connection is in equestrian cultures, in contrast to cultures in which an exclusively equestrian culture develops among the elites, as was the case with knights in the European Middle Ages: in nomadic equestrian cultures, social reality is completely permeated by the horse, which is food, a religious point of reference, and a means of trans-

44 Digard, Une histoire du cheval, $45 \mathrm{ff}$.

45 Similarly, the differentiation between settled and nomadic people only arises around $900 \mathrm{BC}$ with the Scythians; there are no Asian nomads without horses.

46 Of course, scholars from Anglo-American anthropology, such as Cunliffe and especially Anthony, have a completely different opinion: For them, domestication and riding emerge together. Neither, however, are scholars of cultural techniques - unlike Digard, who quotes Mauss, Leroi-Gourhan, and Haudricourt, featuring the former prominently in his Introduction. From this perspective on domestication, concerned with cultural techniques and techniques of the body, the supposedly obvious equation of "man + horse = riding" appears to be the result of protracted processes of mutual transformation requiring complex technical, habitual, and symbolic measures of reconstruction. Asserting that this result is the beginning of this process, as Anthony does, is a retrofitting on the basis of an outcome. Or, to incorporate Latour's distinction between ready-made science and science in the making: it asserts ready-made interspecific culture instead of interspecific cultural techniques in the making. See Bruno Latour, Science in Action: How to Follow Scientists and Engineers through Society (Cambridge, MA: Harvard University Press, 1987).

47 Digard, Une histoire du cheval, 49 and 50, as well as 68. A plain is also necessary in order for it to be possible to gain enough speed with heavy war chariots. Of course, this applies for heavy cavalry, as well. 
port. Everybody learns to ride from a young age, which becomes the only form of movement, even for the shortest distances. Running is absolutely unusual. For this riding culture, the principle of economy applies, i.e., the development of simple, manageable, and pragmatic riding techniques. ${ }^{48}$ It is only logical that the outfit, or clothing, is attuned to such an interspecific technique of the body, which shapes the rider's habitus deep into the apparatus of their muscles. Hence, without the cultural technique of riding and the peoples who would have developed it, there would be no pants (Fig. 3). ${ }^{49}$

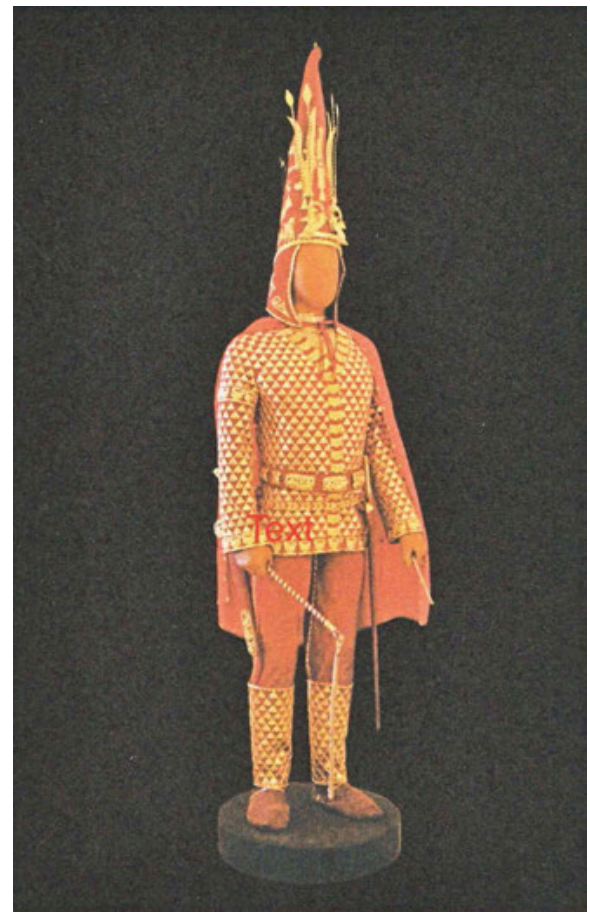

Fig. 3: Reconstruction of the dress of a Saka chieftain, 4th to 3rd century BC (the Saka were a group of nomadic peoples living in the steppe between the Caspian See and the Pamir).

It is therefore no coincidence that the people in Palmyra who did not dress like Romans were Persians, or more precisely Parthians, members of the great empire that existed on the territory of today's Northern Iran from the third century BC to the third century AD. The Parthians were a settled subtribe of the Scythians, a confederation of Indo-European tribes who developed riding, and who invented

48 Digard, Une histoire du cheval, 193.

49 Digard, Une histoire du cheval, 76. 
not only the saddle but also pants and the forging of iron..$^{50}$ Accordingly, the heart of the Parthian army consisted of mounted archers and armored riders, the cataphracts. ${ }^{51}$ This garment then not only spread to Europe from Iran: via the Xiongnu, a nomadic people who rode horses and waged war against the Chinese for centuries, pants also reached the Middle Kingdom..$^{52}$ The extent to which pants were tied to riding is also manifest ex negativo in China: around $300 \mathrm{BC}$, the introduction of mounted archers by the Chinese Emperor almost failed because of the refusal to exchange the long skirt, a sign of social prestige, for the pants that were necessary for riding. ${ }^{53}$

The pants leg simultaneously enables close contact between the human leg and the horse's body, while also protecting the leg and allowing great freedom of movement without fabric fluttering around. Another device was nevertheless needed to attach the feet, and thus also to steer the horse directly: it is well known that the stirrup is one of the most important developments in riding technology, and since the work of Lynn White, its role in the development of European warfare and the caste of knights from the eight century $\mathrm{AD}$ onward has also been known and extensively debated..$^{54}$ Stirrups, however, were also developed in Asia, in a long process of development that began a millennium earlier.

The first fixed metal stirrups were made in Central Asia in the first century AD, presumably in the Kushan Empire (whose territory covered present-day Afghanistan, Pakistan and northern India). Hence the stirrup not only made possible

50 Hermann von Wissmann, "Badw. II: The History of the Origin of Nomadism in its geographical Aspect," in The Encyclopedia of Islam, vol. 1, ed. Hermann v. Wissmann and Friedrich Kussmaul (Leiden: E.J. Brill, 1960), 874-880, 878f.

51 Cunliffe, By Steppe, Desert and Ocean, 258f. Rome later integrated Parthian armored riders into its own army, which represents another common variant of technology transfer: the buying up of know-how. On the cataphracts, see also Digard, Une histoire du cheval, 70f. These were forerunners of the European knights, even without stirrups. They instead utilized other forms of fusing rider and horse through shared armor, which also served to stabilize the rider's position. That is to say: we are dealing here with a form of technical concretion in the sense of Gilbert Simondon because several elements, such as the quiver that holds arrows and stabilizes the rider, are multifunctional. One might therefore ask: is it perhaps the interspecific assemblage that produces the first concrete technical forms? A further factor is the breeding and selection of particularly robust horses, which can, in the first place, carry and bear this form of waging warfare, fought through physical impact, as well as this armor. On the notion of "concretion," see Gilbert Simondon, $D u$ mode d'existence des objets techniques (Paris: Aubier, 1958), $19 \mathrm{ff}$.

52 Von Wissmann, "Badw.," 879.

53 Digard, Une histoire du cheval, 77.

54 Lynn White, Jr., Medieval Technology and Social Change (Oxford: Oxford University Press, 1964), 1ff. 
European knights, but, earlier, the Scythian bow riders from whom the figure of the centaur emerged as we know it from Greek mythology.

It was thus a shrewd costume that Edward III and his courtly entourage had chosen with their Mongol outfits, for without the invention of the stirrup in the Asian steppe, the jousting tournament they held on that September day of 1331 would not have been possible at all.

Of course, warfare had been waged on horseback before; the cataphracts are an obvious example. Bows and arrows had also been used. But the specific tactics of the harcèlement, or the lightning-fast attack and retreat combined with the use of curved composite bows with great penetrative power and reach, required riders firmly supported by stirrups. Only such robust metal stirrups gave knights (in Europe) and archers (on the Asian steppe) the stability in the saddle (even if the cataphracts offer an earlier history of this stabilization) necessary for the development of these dreaded and efficient techniques for waging war.

The human foot, however, is not stable enough to withstand this strain without injury (especially as the first stirrups were extremely narrow bars), which means that riding with stirrups requires riders to wear sturdy footwear, and a nomadic life in the saddle requires riders to wear boots. Stirrups and boots, initially made of hard felt, thus belong together; they are necessarily part of the same technical ensemble or, as Didier Gazagnadou writes, of the same technicalmilitary-political structure.

Il s'agit de penser le problème de l'invention et de l'emprunt des étriers en tant qu'agencement entre le technologique, le militaire et le politique, et donc de mettre en relation étriers, selles, pantalon, bottes, organisation sociale nomade, et de considérer le rapport de ce type de société à l'espace, au cheval et à la guerre. ${ }^{55}$

It is a question of thinking about the problem of the invention and borrowing of stirrups as an arrangement between the technological, the military, and the political, and thus of relating stirrups, saddles, pants, boots, nomadic social organization, and considering the relationship of this type of society to space, the horse, and war.

The war technology of the nomads on the Asian steppe emerges from a political and social system of organization based entirely on the domestication of the

55 Didier Gazagnadou, "Les étriers: Contribution à l'étude de leur diffusion de l'Asie vers le monde,” Techniques \& Culture 37 (2001): 4; http://tc.revues.org/266 (visited on August 16, 2017); my translation. Hence, this contradicts Lynn White and all his genealogies, based on the inability to conceive of other, advanced civilizations (India and China) as the inventors of something as important as stirrups. And: aspandak, the Persian word for stirrup, means "attache à cheval," which reminds us that we are dealing here with a history of attachments between species, and hence of quite specific technical attachments, namely montage. 
horse: a social system of organization that exists between species, and a culture of riding that is not reserved for an elite but in which everyone participates. This culture distinguishes itself (just like that of the nomadic Arabs, who were early adopters of the stirrups) by agility, archery, and the harcèlement, and this technical ensemble also includes metallurgy (since functional stirrups must be made of metal) as well as the manufacture of boots. This footwear, common today in Europe, also came to us from Asia, from Turko-Mongol nomadic peoples. And the migration of these elements of the ensemble reveals in turn: such elements can be separated from their original ensemble at any time. Even if pants, stirrups, and boots belong together: they were exported to societies that were settled and in which riding was an elite culture. And, of course, pants and boots could eventually become completely detached from the cultural technique of riding.

\section{Techniques for Wearing Clothing and Carrying Loads}

But such observations cannot only be made for footwear and legwear (which, in any case, developed late in Europe). In a text from 1948 entitled "Relations entre gestes habituels, forme de vêtements et manière de porter des charges” (Relationship between habitual gestures, the shape of clothing and the manner of carrying loads), another Mauss disciple, André-Georges Haudricourt (who often stands in the shadow of Leroi-Gourhan), ${ }^{56}$ noted that the Europeans of antiquity knew only two types of clothing: a type of tunic wrapped around the body, and a type of poncho, originally with an opening that was pulled over the head (as we do today with T-shirts or sweaters). ${ }^{57}$ One would also have to include in this category the tabard, which knights wore over their armor. ${ }^{58}$ Many of these garments

56 Yet see also Erhard Schüttpelz, "Die medienanthropologische Kehre der Kulturtechniken," Archiv für Mediengeschichte, 6 (2006): 87-110, and Cuntz, "Kommentar zu André-Georges Haudricourt."

57 André Georges Haudricourt, "Relations entre gestes habituels, forme de vêtements et manière de porter des charges, “ in A.G.H., La technologie science humaine: Recherches d'histoire et d'ethnologie des techniques (Paris: Editions de la Maison des sciences de l'homme, 1987), 171-182, here 175 .

58 Hence the word tabard has nothing to do with the garment known in German as a Tappert (Duden: "a cloak-like coverlet from the fourteenth and fifteenth centuries worn mostly by men"), despite the obvious derivation of the German word from this source; the Tappert corresponds, instead, to the houppelande. 
were therefore loosely fitted to the body and did not even require sewing, ${ }^{59}$ which means that cutting the fabric to size was either not practiced or at least played a minor role. ${ }^{60}$

Garments such as jackets, waistcoats, coats, or shirts that are open at the front and can be closed with buttons or the like were, however, unknown. As the first Western garment of this type, Haudricourt identifies the houppelande, or in German, Tappert, which first appears in the thirteenth century ${ }^{61}$ and was replaced in the fifteenth and sixteenth centuries by the Schaube (a gown or robe with sleeves), which, unlike the Tappert, is worn open like a vest. (Fig. 2) Haudricourt traces the French and Spanish words for vest, "gilet" and "jaleco," back to the Turkish word "yelek" (in contemporary Turkish, this is still the word for vest), and thus to a nomadic origin. The process of introducing such garments into Europe therefore took place between the thirteenth and sixteenth centuries, with the beginning of the Mongol "fashions," and at the same time of the panni tartarici and the hennins: if one follows Haudricourt's chronology and genealogy, their marginalization thus conceals simultaneous processes of the Asianization of European clothing that carry a far greater significance. ${ }^{62}$

Haudricourt then connects the development of clothing with the development of techniques for carrying. He distinguishes between active carrying, in which the arm muscles are constantly tensed and placed under stress, and passive carrying, which is more economical because it can be integrated into the movements of the muscles by holding an upright posture and walking. ${ }^{63}$ Like Marcel Mauss, Haudricourt begins with habitual gestures and thus techniques of the body, and with the assumption that there is a development from active carrying to passive, energy-saving carrying. He attests a dominance, in Europe in the 1940s, of active carrying and thus a backwardness in comparison to other parts of the world, including Asia; for passive carrying, he distinguishes several possibilities, each of which produced different objects and fastening mechanisms. ${ }^{64}$

59 Veyne, Palmyre, 12.

60 Haudricourt, "Relation entre gestes habituels," 177.

61 Confirmed by the Petit Robert. Houppelande dates to the fourteenth century; its precursor form hopelande dates back to 1280 .

62 Haudricourt, "Relation entre gestes habituels," 176.

63 Haudricourt, "Relation entre gestes habituels," 173.

64 The fact some things never change is shown by the malicious attack of the television personality Piers Morgan on Daniel Craig, for carrying his baby in a papoose, as an "\#emasculatedBond"; see "Piers Morgan mocks Daniel Craig for carrying baby,” https://www.bbc.com/news/uk-45873664 (visited on July 22, 2019). Sonja Haller: "Piers Morgan ridiculed James Bond actor Daniel Craig for wearing a baby carrier ... in 2018,” https://eu.usatoday.com/story/life/allthemoms/2018/10/16/ piers-morgan-mocks-daniel-craigs-manhood-wearing-baby-carrier/1658291002/ 
Regarding gestures and movements not as natural, but as a culturally developed reservoir of techniques of the body, learned in the same way as the phonology of individual languages, also means regarding supposedly banal sequences of movement, such as carrying, to be the result of long developmental processes. In this view, certain cultures have only certain forms of active and passive carrying, which in turn form the physical habitus and thus imprint themselves on and implant themselves into the body. There is thus a fundamental difference between attaching a carried load to the head, or with straps crossed over the chest.

Another, separate form of attachment is that with parallel shoulder straps, as is the case with backpacks. This requires a sequence of movements that Haudricourt does not at all take for granted, but which he sees as the result of a longer learning process relating to techniques of the body: of putting the straps on one after the other. Haudricourt then notices that the same, comparatively complex, sequence of movements is carried out when one slips on a shirt or jacket, which brings him to the conclusion that the manner of carrying loads and wearing clothes, the gestures, and corresponding objects emerged at the same time. Indeed, the backpack or winegrower's vat, which is also fastened with straps, arrived in Europe at about the same time as the jacket. ${ }^{65}$

As the first known representation in Europe of a garment of this type, he names an illumination in a manuscript from the turn of the tenth to the eleventh centuries. It depicts a Bulgarian warrior. ${ }^{66}$ As one learns from the archaeologist Barry Cunliffe, the Bulgarians were originally an Asian nomadic tribe from the Pontic-Caspian steppe that was driven out to the Balkans in the seventh century by the Khasars, a Turkic tribe, but had previously likely adopted the clothing of those who displaced them, or of the ethnic groups related to them. ${ }^{67}$ According to Haudricourt, the first wearers of garments adapted to the body, i.e., requiring the fabrics to be cut to size, that are open at the front and pulled on as one puts on a backpack, by slipping into the straps, were Turkic peoples and the Mongols, who also introduced these garments in China. Anyone today who wears pants,

(visited on July 22, 2019). The white, Eurocentric virility-fetishist Morgan finds it unmanly that Craig makes use of an Indian technique of passive carrying instead of stupidly wasting his energy by actively carrying his baby in his arms - like the Greeks, who preferred to ride their crotch raw without a saddle (bareback) rather than use unmanly Asian saddles. Those harping on this old tune, however, definitely do not seem to become much smarter over the centuries.

65 Haudricourt, "Relations entre gestes habituels," 178. It can be proven that in Asia, too, this spread occurred simultaneously (see 179f).

66 Haudricourt, "Relations entre gestes habituels," 177.

67 Cunliffe, By Steppe, Desert and Ocean, 324f. 
sturdy shoes, a blouse, a sweater, a shirt, or suits is wearing clothing developed by nomads of the Asian steppe: Monturen made of bodies, fabrics, gestures, and environments.

\section{Interspecific Montagen/montures instead of Anthropocentric Projections}

Even if Haudricourt does not identify, in "Entre gestes habituels, forme de vêtements et manière de porter des charges," any direct causality between the domestication of animals and the emergence of this form of carrying loads and clothing, he still does give a brief but relevant reference in his text. Nomadic peoples in the far north of Asia use reindeer and dogs as motors to pull loads transported on sledges. These animals are harnessed with shoulder straps crossed over their chest.

As discussed above, more than fifty years later Didier Gazagnadou pointed out for the assemblage or outfit of pants/saddle/boots/stirrups that the entire social organization of the nomads and their relationship to space must be taken into account. ${ }^{68}$ Given this fact, a logical conclusion can be drawn from Haudricourt's entire ethnobiological approach, with its attention to energies, gestures, and habits: it is probably no coincidence that in a nomadic society whose mobility implies the permanent transport of loads, the most efficient and, as Haudricourt puts it, "passive" forms of carrying loads are formed, or are spread and adapted from this origin.

Haudricourt's deliberations must be supplemented by the idea that, in addition to the perfect use of one's own body, the delegation of carrying (including in the transformation of movement into pulling), i.e., having something be carried (or pulled), is an efficient form of passive carrying: make do instead of doing it yourself. What is equally obvious is the connection between locomotion and warfare on horseback and an optimization of clothing that requires hides, skins, or fabrics to be cut in order to achieve a better fit and thus the greatest possible freedom of movement, as we have already observed for pants. This becomes necessary in a climate in which, unlike in India, for example, wearing clothing is essential for survival.

68 Gazagnadou, “Les étriers.” 
Especially Haudricourt's works on animal motors (above all in mills) ${ }^{69}$ and the resulting forms of movement of animals and machines - and (to a certain extent) any confrontation with domestication processes that examines practices and gestures - demonstrate how problematic it is to generalize the anthropocentrichylomorphistic organ projection thesis, formulated by the pseudo-technical philosopher Ernst Kapp, ${ }^{70}$ beyond the purely phantasmatic dimension that made it so attractive for Freud and his discourse about "a kind of prosthetic God,"71 or McLuhan's model of narcissism and narcosis. ${ }^{72}$ What actually applies to the ear, i.e., the reproduction of the functional mechanism of the perceptual organ in technical objects such as loudspeakers, cannot be transferred to other organs and certainly not to motor processes. ${ }^{73}$ Rather, it proves to be a projection of the human or perhaps only the European desire to be the origin and starting point of everything.

But in riding, it is not simply that the legs of human beings are projected over the stirrup into the horse and its legs; rather, both horse and rider must habitually incorporate the body of the other living creature until the muscular and perceptive apparatus of the human being changes. It is not only that the horse learns various gaits or to move with a carriage, wagon, or cart; riding also requires the activation of different human muscle groups than those used in running. Horses have learned to perceive and interpret the smallest muscle movements of human beings, and the view of the world from the horse's back is different than on foot, especially when it comes to perceiving and mastering distances. To these are added gestures and movements performed on another living being, such as grooming or putting on a harness. Dealing with the animal's body requires exploring the animal's characteristics and anatomy; it requires objectifying and analyzing what can be done with this familiar yet alien body, what this body can be made to do, what it can bear, carry, and endure. Hence, what would it mean if

69 André-Georges Haudricourt, "Les moteurs animés en agriculture," in A.G.H., La technologie science humaine, 157-167, see also Haudricourt, Des gestes aux techniques: Essai sur les techniques dans les sociétés pré-machinistes, ed. Jean-François Bert (Paris: Maison des sciences de l'homme, 2010), 117-126. On this question, see also Schüttpelz, "Die medienanthropologische Kehre," 87-110.

70 Ernst Kapp, Grundlinien einer Philosophie der Technik (Braunschweig: G. Westermann, 1877). 71 Sigmund Freud, Civilization and its Discontents, trans. James Strachey, in The Standard Edition of the Complete Psychological Works of Sigmund Freud, vol. XXI (1927-1931) (London: Vintage, 2001), 91-92.

72 Marshall McLuhan, Understanding Media: The Extensions of Man (London and New York: Routledge, 2001 [1964]), 45-52.

73 For the analogy between ears and soundboxes, see, for example, Michel Serres, “Caisses," in M.S., Les cinq sens (Paris: Grasset, 1985). 
the development of a new gesture of putting something on and pulling it over had taken a detour via the practice of attaching a device for harnessing draft animals, or at least that there was an interspecific exchange between the attachment of loads and vehicles to human and animal bodies? ${ }^{74}$

Haudricourt, who always also includes the history of naming in his considerations, notes that the French word for a bridle, "bretelle," was not used until the thirteenth century. The word derives from the Old High German "brettil" or "brittil," which itself refers to nothing other than the bridle of the horse. ${ }^{75}$ The word was therefore apparently used first for riding or draft animals and only thereafter for vessels or containers attached to the human body and, finally, for the clothing itself. ${ }^{76}$ Moreover, the bridle, too, was in all probability invented by Mongols. ${ }^{77}$ In French, this relationship can still be seen in the similarity of the words "bretelle" and "bride," both of which derive from "brittil."

Domesticated animals, above all horses, were therefore not only indispensable as transport media in overcoming the distances that made the migration of objects throughout Eurasia possible. In addition, their domestication and the techniques of riding and pulling have themselves produced objects, namely garments, that spread from the steppes and high plateaus of Asia to China and Europe, and from Europe to the whole world. The reality of these Eurasian migration processes of cultural techniques and things, without which neither our current technical civilization nor the global economic networks that have existed for millennia would have emerged, is not a phantasmatic projection or externalization of the human being and its organs into its environment, from the inside out, as every anthropocentric hylomorphism would have it. Rather, it is the formation of interspecific and milieu-dependent Monturen or assemblages composed of animals, human beings, and gestures.

74 In L'utilisation de l'énergie naturelle, Haudricourt nevertheless identifies (one must concede) direct transmissions from humans to animals in northern Asia and America: "certain dog or reindeer teams that appear to be directly inherited from the human mode of pulling" (186). In any case, however, there is central technical problem to be solved: how to efficiently fasten something to the body of an animal?

75 Haudricourt, "Relations entre gestes habituels," 178.

76 Althochdeutsches Wörterbuch des Wörterbuchnetzes, http://awb.saw-leipzig.de/cgi/WBNetz/ wbgui_py?sigle=AWBode=Gliederungemid=AB02951\#XAB02951 (visited on August 16, 2017).

77 See Goody, Theft of History, 188. 